Management Dynamics

Vol. 23, No. 1: 253-260, 2020

Shanker Dev Campus

Doi: https://doi.org/10.3126/md.v23i1.35584

\title{
Entrepreneurial Productivity of Single and Non Single Women of Kathmandu Metropolitan City
}

\author{
Ratna Mani Nepal* \\ Om Kumari Ramtel ${ }^{* *}$
}

\begin{abstract}
Despite that women's socio-economic status is poor, there involvement in entrepreneurial development is low. Data shows that women's participation in income generating activities and their access to property is quite unsatisfactory. Globally, only eight percent small scale-manufacturing units are owned and operated by women. Compared to the universal statistics, Nepal's scenario is different because the country owns more than six lakhs small scale manufacturing units. In these units women's participation is relatively higher. Certain ethnic community, especially the Newar and Tibeto-Burman highland groups such as the Sherpa, Gurung and Thakali, are known to have a long tradition of women being involved in small business enterprises. However, women's ownership of these enterprises is extremely low. This study aims to examine the entrepreneurial status of single and non-single women who are engaged in entrepreneurial activities in Kathmandu Metropolitan city. It also analyzes the entrepreneurial productivity of the enterprises run by the women. In order to discuss the objectives, primary data was collected from field work. This study found that single women's involvement in the small businesses was encouraging. The entrepreneurial productivity of the enterprises run by singlewomen was higher than non-single women.
\end{abstract}

Key words: Women, Small enterprises, Entrepreneurship, Investment, Capital output ratio

\section{Introduction}

Despite that women's socio-economic status is poor, there involvement in entrepreneurial development is low. According to Central Bureau of Statistics (CBS, 2018), only 29.8 percent businesses are owned by women. Data show that only 19.7 percent women own land. This is only 5 percent of the total land of Nepal. Of these women only 11 percent women have control over their land (The Women's Foundation, Nepal, 2021). This shows that women's participation in income generating activities and their access to property is quite unsatisfactory.

Globally, only eight percent small scale-manufacturing units are owned and operated by women. Compared to the universal statistics, Nepal's scenario is different because the country owns more than six lakhs small scale manufacturing units. In these units women's

\footnotetext{
* Lecturer, Central Department of Rural Development [ratna.nepal@cdrd.tu.edu.np]

** [ramteljee740@gmail.com]
} 
participation is relatively higher. Certain ethnic community, especially the Newar and Tibeto - Burman highland groups such as the Sherpa, Gurung and Thakali, are known to have a long tradition of women being involved in small business enterprises. However, women's ownership of these enterprises is extremely low. The situation becomes worse if the status of single women is concerned. Given development perspectives, lower participation of women in economic activities is inversely proportional to economic growth and development. Hence, investing in women's capabilities and empowering them to exercise their choices is not only valuable but is also the surest way to contribute to economic growth and overall development.

Single women are generally known as widows as defined by our society. Divorced women are also included as a single woman. Government of Nepal has defined the term for single women as divorced women, widows, unmarried women over 35 years' old, women without husband for more than five years, and separated women by taking her share of property from husband (GoN, 2013). Thus, the women within the bracket of these five limitations are known as single women in Nepal.

Regmi (2006) argues that there is a need for empowerment and transformative approaches among women as in individual or in collective form to reduce their powerlessness so that they gain greater control over aspects of their lives and social environment. In this context, women's entrepreneurship needs to be studied separately for two main reasons. The first reason is that women's entrepreneurship has been recognized recently as an important untapped source of economic growth but not addressed. Women entrepreneurs create new jobs for themselves and others. For being different, they also provide the society with different solutions to management, organization and business problems as well as to the exploitation of entrepreneurial opportunities. However, they still represent a minority of all entrepreneurs (Federation of Women Entrepreneurs Association of Nepal [FWEAN], 2018). Thus, there exists a market failure discrimination against women's possibility to become entrepreneurs and their possibility to become successful entrepreneurs. This market failure needs to be addressed by policy makers so that the economic potential of this group can be fully utilized (OECD, 2004).

The second reason is that the topic of women in entrepreneurship has been largely neglected both in society in general and academic works. Not only have women lower participation rate in entrepreneurship than men but they also generally choose to start and manage firms in different industries than men tend to do. The industries (primarily retail, education and other service industries) chosen by women are often perceived as being less important to economic development and growth than by the use of high technology and manufacturing (OECD, 2004).

Furthermore, mainstream research, policies and programs tend to be "men streamed" and too often do not take into account the specific needs of women entrepreneurs and would-be 
women entrepreneurs (OECD, 2004). As a consequence, equal opportunity between men and women, from the perspective of entrepreneurship, is still not a reality (Rashmi, 2016).

Women have always comprised half the population in the world but rights according to women have not been at par with their male counterparts. Discriminatory practices against women have a long history and in every society discrimination in same or the other forms have always existed. Social malpractices such as child marriages polygamy and stoning to death of women accused of witchcraft were practices that have existed in Nepal in the past (WHR, 2010). While struggling to improve their lives in an environment of high unemployment and political unrest over the past ten years, more and more Nepalese women have entered into private enterprise.

The history of entrepreneurship development programs in Nepal is quite recent. While Nepal has been in the development of small - scale and microenterprises since the late seventies, issues and questions relating to the promotion of women entrepreneurs have only been raised more recently (Chaudhary, 2015). With the political change in 1950, Nepal got the first women entrepreneur, named Hajuri Bista. That was also the time when multiparty democracy system had just emerged and opportunities were opening up. With continuous learning along with training and individual effort, Hajuri Bista started her pickle business. Therefore, what one should learn is that, wherever a person works, favored by change of political situation, its consequences lead to the changed landscape and involvement of women in business (Greentick, 2018).

This study aims to examine the entrepreneurial status of single and non-single women who are engaged in entrepreneurial activities in Kathmandu Metropolitan city. It also analyzes the entrepreneurial productivity of the enterprises run by the women. Entrepreneurial productivity is the ratio between capital investment and profit earned by the firm.

\section{Methodology}

This study is exploratory and descriptive in nature. Data was collected by applying semistructured questionnaire and key-informants interview schedule in ward no 32 of Kathmandu Metropolitan city. The list of small and cottage industries of women entrepreneurs was obtained from Federation of Women Entrepreneurs Association of Nepal (FWEAN). There were altogether 103 small and cottage industries run by women entrepreneurs in Kathmandu Metropolitan city. Out of elected 19 executive members, 15 executive members of FWEAN of non-single women category have been selected purposively as key informants. For the purpose of comparison, fifteen single women entrepreneurs were selected by applying snowball method. Similarly, the secondary data has been collected from various published sources. 


\section{Data analysis and interpretation}

\section{General characteristics of the respondents}

Majority of the respondents were above 40 years age. By ethnicity, 60 percent respondents were Newars. By education, 90 percent women had completed school level education. Of them, 56 percent had educational attainment above higher secondary level. Fifty percent women respondents were involved in various types of social organization. In the associations of commerce and business, above 60 percent had gotten membership. The organizations are associations of female entrepreneurship in Kathmandu.

\section{Enterprises and entrepreneurial productivity of women}

The main purpose of the study was to assess the small enterprises run by single and nonsingle women in Kathmandu Metropolitan city. In this section, the status of enterprises run by women and their productivity is analyzed.

\section{Sources of fund for business}

The highest percentage of women entrepreneurs were found to be investing their own family's capital in the enterprises but bank finance was taken by few of them. Very few respondents were getting bank loan due to lengthy acquiring process. If it is made easier to get bank loan, then the numbers of women entrepreneurs may increase.

Table 1: Source of business start up

\begin{tabular}{|l|l|l|}
\hline \multirow{2}{*}{ Source of business start up } & \multicolumn{2}{c|}{ Responses } \\
\cline { 2 - 3 } & Frequency & Percent \\
\hline Household source & 20 & 60.0 \\
\hline Loans from informal source & 4 & 20.0 \\
\hline Loans from formal source & 3 & 15.0 \\
\hline Property Sell & 2 & 3.8 \\
\hline Sell of another business & 1 & 1.2 \\
\hline Total & $\mathbf{3 0}$ & $\mathbf{1 0 0}$ \\
\hline
\end{tabular}

Source: Field Survey, 2019

Above table shows that total of 20 respondents (60\%) has started business getting fund from their own household and personal savings. Informal sources such as friends and relatives include $20 \%$ while $15 \%$ respondents got loans from formal sources. Sell of personal and relatives business was also source of fund to start businesses.

\section{Initial investment of respondent}

In the study area researcher found some of the respondents initiating their business with minimum investment (Rs. 1 one lakh). The upper limit of the initial investment made by the respondent women was above forty lakh. Of the total respondents, 60 percent started their business with investment in-between 1 to 10 lakh. Similarly, 28 percent respondents started 
their business with less than 1 lakh of investment. Very few, only one percent respondents had invested in between 31 to 40 lakh in their business. The current capital of the enterprises ranged between one lakh to above one crore.

\section{Average annual income}

The women's annual income from the small businesses was satisfactory. For some respondents the financial gain was highly encouraging to continue with the business. In the study area, women's annual income ranged between 1-10 lakh to above one crore. A majority women respondents (30\%) earned between 11-20 lakh.

The income respondents earned was also distributed to the wider population due to employees the enterprises employed. At the minimum one to at the maximum 180 number of employees were employed in the business. This meant an encouraging sign of entrepreneurship development by the respondent women.

\section{Ratio between expenditure and earning}

The ratio between expenditure and earning shows the real status of the business. In actual situation, there must be three situations in business like profit, loss and breakeven. Researcher did not find the status of loss in the study area. Researcher found only profit and breakeven status. And with the help of cross tabulation researcher tried to show the combination of time spend in the business by women entrepreneurs in the study area. The ratio between expenditure and earning and time spend in business is shown in table.

Table 2: Ratio between expenditure and earning and time spend in business

\begin{tabular}{|l|l|l|l|l|l|}
\hline \multicolumn{2}{|c|}{ Cross Tabulation } & \multicolumn{3}{c|}{ Time spend in business } & \multirow{2}{*}{ Total } \\
\cline { 3 - 6 } \multicolumn{2}{l|}{} & $\mathbf{1 - 5}$ hrs. & $\mathbf{5 - 1 0}$ hrs. & Above 10 hrs. & \\
\hline $\begin{array}{l}\text { Ratio between Expenditure } \\
\text { and Earning }\end{array}$ & Profit & 2 & 21 & 3 & 26 \\
\cline { 2 - 6 } & Breakeven & 1 & 3 & 0 & 3 \\
\hline Total & $\mathbf{3}$ & $\mathbf{2 4}$ & $\mathbf{3}$ & $\mathbf{3 0}$ \\
\hline
\end{tabular}

Source: Field Survey, 2019

Table shows that highest i.e. 70 percent women entrepreneurs had found profit in their business (this is the ratio between expenditure and earning) and they spent 5-10 hours of their time to their business. Another 10 percent invested above 10 hours per day, while 6 percent invested between 1-5 hours. Likewise, 7 percent women entrepreneurs had neither lost nor got profit (in breakeven position) in their business, who spent 5-10 hours' time to their business.

The detail of the respondent's annual capital expenditure and earning and the ratio between the two is given in the table below. 
Table 3: Single women entrepreneurs of Kathmandu metro city

\begin{tabular}{|r|l|l|r|r|r|r|}
\hline \multicolumn{1}{|c|}{ SN } & \multicolumn{1}{|c|}{ Name } & \multicolumn{1}{c|}{ Caste } & \multicolumn{1}{c|}{ Capital } & \multicolumn{1}{c|}{ Profit } & \multicolumn{1}{c|}{ Ratio } \\
\hline 1 & Kripa & Shrestha & 35 & 2000000 & 400000.00 & 20 \\
\hline 2 & Dibya Ratna & Tuladhar & 36 & 1500000 & 170000.00 & 11.333 \\
\hline 3 & Basu Maya & Tamang & 40 & 1600000 & 250000.00 & 15.625 \\
\hline 4 & Sharda & Limbu & 44 & 400000 & 300000.00 & 75 \\
\hline 5 & Devi & Gurung & 34 & 600000 & 200000.00 & 33.333 \\
\hline 6 & Reshmi & Pariyar & 46 & 1500000 & 300000.00 & 20 \\
\hline 7 & Kamala & Dahal & 32 & 1300000 & 400000.00 & 30.769 \\
\hline 8 & Rukmani & Shrestha & 42 & 1200000 & 350000.00 & 29.167 \\
\hline 9 & Radha Laxmi & Shrestha & 40 & 750000 & 200000.00 & 26.667 \\
\hline 10 & Leela & KC & 38 & 2500000 & 500000.00 & 20 \\
\hline 11 & Khina & KC & 36 & 3000000 & 600000.00 & 20 \\
\hline 12 & Kamala & Shrestha & 40 & 2500000 & 550000.00 & 22 \\
\hline 13 & Kabita & Pandey & 35 & 700000 & 150000.00 & 21.429 \\
\hline 14 & Sumitra & Subedi & 33 & 1000000 & 300000.00 & 30 \\
\hline 15 & Kalpana & Limbu & 42 & 2000000 & 350000.00 & 17.5 \\
\hline & Average & & 38.867 & $\mathbf{1 5 0 3 3 3 3 . 3}$ & $\mathbf{3 3 4 6 6 6 . 6 6 7}$ & $\mathbf{2 6 . 1 8 8}$ \\
\hline
\end{tabular}

Source: Field Survey, 2019

This table shows that single women entrepreneur had invested maximum 2 corer to minimum 4 lakhs. The profit they earned annually ranged between Rs. 150,000 to Rs. 4,00,000. The average ratio between capital to the profit was 26.188 .

Table 4: Non Single Women Entrepreneurs of Kathmandu Metro City

\begin{tabular}{|r|l|l|r|r|r|r|}
\hline SN & Name & Caste & Age & Capital & Profit & \multicolumn{1}{l|}{ Ratio } \\
\hline 1 & Sarojani & Serchan & 40 & 20000000 & 7000000.00 & 35 \\
\hline 2 & Basanti & Pradhan & 45 & 15000000 & 1700000.00 & 11.333 \\
\hline 3 & Mahalaxmi & Shrestha & 33 & 1600000 & 250000.00 & 15.625 \\
\hline 4 & Sharada & Rijal & 42 & 4500000 & 800000.00 & 17.778 \\
\hline 5 & Ramala Kumari & Pokharel & 46 & 3000000 & 200000.00 & 6.6667 \\
\hline 6 & Sumitra & Palanchoke & 32 & 1500000 & 300000.00 & 20 \\
\hline 7 & Saraswati & Parajuli & 42 & 1300000 & 400000.00 & 30.769 \\
\hline 8 & Maya & Nepali & 40 & 1200000 & 350000.00 & 29.167 \\
\hline 9 & Ritu Singh & Vaidhya & 32 & 4500000 & 800000.00 & 17.778 \\
\hline 10 & Shova & Gyawali & 36 & 2500000 & 500000.00 & 20 \\
\hline 11 & Darsana & Shrestha & 36 & 3000000 & 600000.00 & 20 \\
\hline 12 & Sabita & Das & 40 & 2500000 & 550000.00 & 22 \\
\hline 13 & Sunita & Vaidya Shrestha & 47 & 400000 & 150000.00 & 37.5 \\
\hline 14 & Shrijana & Tuladhar & 34 & 1000000 & 300000.00 & 30 \\
\hline 15 & Maya & Gurung & 46 & 12000000 & 1350000.00 & 11.25 \\
\hline & Average & & 39.4 & $\mathbf{4 9 3 3 3 3 3 . 3}$ & $\mathbf{1 0 1 6 6 6 6 . 6 7}$ & $\mathbf{2 1 . 6 5 8}$ \\
\hline
\end{tabular}

Source: Field Survey, 2019 
In this table a detail of non-single women entrepreneurs' business status is given. It shows that their capital investment ranged between Rs. 4,00,000 to Rs. 1,20,000,00. The profit amount ranged between Rs. 1,50,000 to Rs. 1,35,000,00. The ratio between the two variable is 21.658.

In order to examined the productivity variation of the enterprises run by the two groups of women, a comparison of the ratio between capital investment to profit of the single and nonsingle women was done. It shows that single women entrepreneur's capital investment to profit ratio is greater than non-single women entrepreneur.

\section{Opportunities and challenges of the women's businesses}

Women owned enterprises had domestic as well as international market. They were getting demand from Kathmandu valley as well as from Europe and the United States of America. Women had been getting opportunities to participate in training activities that had multiple benefits in their career. More than 50 percent got chance to join industrial tour across the country. This added to their entrepreneurial capacity to run a business. Women entrepreneurs spent more than half of their life time in the entrepreneurship, Hence, they deserved to be rewarded as entrepreneur women. There were more than fifty percent women entrepreneurs who were rewarded in their entrepreneur's life. Being rewarded, they were inspired and motivated in the further stage of their business.

In contrast, the women entrepreneurs faced some challenges in their business career. The foremost problem was initial capital formation. The pressing problem was delay in firm registration and irresponsible behavior of employees. This act could demotivate them to leave the idea to register a business. Staff management seemed another issue in the women's enterprises. Few other problems that the women respondents facing were lack of raw material, customer's behavior, and frequent shift in government policies related to small businesses.

\section{Conclusion}

This study showed that entrepreneurial productivity of single women was higher than nonsingle women entrepreneurs. Socio- economic status of women entrepreneurs in the study area was quite encouraging due to the profit they earned, and management of women in business enterprises. All of them were in profit and socio economic status from age, race, education, etc., were found satisfactory.

Productivity (Capital profit Ratio) of enterprises run by single and non-single women showed that single women were more productive than non-single women who had high capital and family support. Despite family support and high amount of capital investment, single women were performing quite well in their business career. Single women entrepreneur' capital investment to profit ratio was higher $(26 \%)$ than non-single women entrepreneur $(21 \%)$. This showed that policy maker should pay a due attention to encourage single women to initiate businesses.

Opportunities for women entrepreneurs had specific market area, training facilities in different level, industrial visit and rewards. These meant the means of motivation to the respondent women. The challenges of enterprises run by single and non-single women were associated with registration procedures, startup capital formation, and staff management. 


\section{References}

Adhikari, S. R. (2017). Nepal: Women's Economic Participation . Public Private Dialogue (pp. 1-5). Federation of Woman Entrepreneurs' Association of Nepal (FWEAN).

Basnet, L. (2017). Role of women entrepreneurship in small-scale and cottage industries: A case study of Dang district. An unpublished MA Thesis submitted to the Central Department of Rural Development, Tribhuvan University.

Binayak Regmi. (2006). Socio- cultural status of widow and its impact on their livelihoods. An Unpunished thesis submitted to the Central Department of Rural Development, Tribhuvan University.

Chaudhary, M. K. (2015). Entrepreurship development in Nepal. Ayam publication and distributors.

FWEAN. (2018). Enterprising Women Nepal. Federation of Women Entrepreneurs Association Nepal (FWEAN).

GoN (2018). National Economic Census, 2018. Central Bureau of Statistics.

GoN. (2013). Single women security fund (operational) Regulation-2070. Kathmandu: Nepal Law Commission.

Greentick, M. (2018). Development of women entrepreneurship in Nepal. NA.

Istanbouli, A. D. (2015). The role of palestinian women entrepreneurs in business development. University of Granada, Faculty of Economics Science and Business Studies.

Khandey, M. (2015). Empowerment of women in India: Historical perspective. European academic research.

Kyalo, T. N. (2013). Factors that influence women entrepreneurs in kenya to start enterprises in male dominated sectors of the economy. The Jomo Kenyatta University of Agriculture and Technology.

OECD. (2004). Women's Entrepreneurship: Issues and Policies . Organisation for Economic Cooperation and Development (OECD) .

Rashmi, D. (2016). Women Entrepreneur in Micro, Small and Medium Enterprises in India An overview. International Journal of Managerial Studies and Research (IJMSR) Volume 4, Issue 2, February, p. 60-64.

Regmi, B. (2006). Socio-cultural status of widows and its impact on their livelihood, A study on widows in Dang district. An Unpublished Thesis Submitted to Central Department of Rural Development, Tribhuvan University.

WHR. (2009). Community reintegration and rehabilation of migrant and displaced single women (widows). Poverty Alleviation Fund and World Bank.

WHR. (2010). A journey towards empowerment $\mathcal{E}$ the status of single women in Nepal. WHR.

Yogita, S. (2013). Women entrepreneur in India. Journel of Business and Management (IOSR -JBM), Volume 15 (3), p. 9-14. https:/ / pdfs.semanticscholar.org/a839/9756d4faf5937 3852a9b905b1159947a93e3.pdf 